UDC 572

DOI: $10.17223 / 2312461 \mathrm{X} / 26 / 10$

\title{
RELIGION IN THE STRUCTURE OF CULTURAL IDENTITIES IN RUSSIA
}

\section{Olga Kazmina}

\begin{abstract}
Sociological surveys show that most citizens of Russia identify with specific religious traditions. At the same time, most of the surveys about religious make-up, show a big gap between the number of those who consider themselves to be believers and those who actually practice their religious beliefs (that is, attend religious services, pray regularly, and observe religious doctrines and rituals). Moreover, there are also those who do not call themselves believers but associate themselves with a specific denomination. The goal of this article is to interpret these figures and explain this apparent paradox. The author argues that these peculiarities are rooted in specific interconnections of different types of cultural identities, first of all religious and ethnic identity. The interconnection of religion and ethnicity is grounded in Orthodox doctrine itself and in the principle of autocephalous churches. But in Russia the interconnection of religion and ethnicity also has been fostered and promoted by the state. One of the state's effective levers in the construction or shaping collective cultural identities is the population census. The article demonstrates how censuses have contributed to and cemented the close interconnection of religion and ethnicity in Russia and how this interconnection has shaped the specifics of religiosity in contemporary Russia.
\end{abstract}

Keywords: religion, ethnicity, cultural identities, census of population, sociological survey, Russia

All recent sociological surveys show that the majority of Russian citizens identify themselves with a specific religious tradition, first of all Russian Orthodoxy (between 64 percent and 75 percent in the surveys conducted in the second decade of the 21 st century). At the same time, most of the surveys about religious make-up, show a big gap between the number of those who consider themselves to be believers and those who actually practice their religious beliefs (that is, attend religious services, pray regularly, and observe religious doctrines and rituals). Only 5 to 7 percent of believers are actively involved in institutionalized religious activities (Zaluzhnyi 2002: 45). Moreover, there are also those who do not call themselves believers but associate themselves with a specific denomination.

The goal of this article is to interpret these figures and explain this apparent paradox. My argument is that the paradoxical gap between the numbers of those who associate and those who believe, the relatively low number of those who call themselves non-believers, and the high number of those who call themselves Orthodox, are rooted in specific interconnections of different 
types of cultural identities, first of all religious and ethnic identity. The figures in the surveys can be explained by the place of religion (or more precisely religious identification) in the structure of collective cultural identities. The interconnection of religion and ethnicity is grounded in Orthodox doctrine itself and the principle of autocephalous churches. Orthodox teaching itself contains ideas of national (or other collective) identity (Prodromou 2004: 30-31). In Russia the interconnection of religion and ethnicity also has been fostered and promoted by the state. One of the state's effective levers in the construction or shaping collective cultural identities is the census of population.

According to the UN's definition, "a population census is the total process of collecting, compiling, evaluating, analysing and publishing or otherwise disseminating demographic, economic and social data pertaining, at a specified time, to all persons in a country or in a well delimited part of a country" (Principles 1988). Therefore, it is essential to note that the census is perceived as an important and reliable source of data about population. It is often figuratively compared with a photograph or a reflection in mirror. According to David Kertzer and Dominique Arel, who were the first to point it out, the census also plays a key role in the construction of social reality (Kertzer 2002: 2). The census is a tool in the state's hands to categorize the population. The categories fixed by the census acquire greater significance in people' minds. Through the census, the state transmits to population its scale of values in the structure of collective cultural identities and thereby contributes to identity construction and the hierarchy of various types of identities.

In Russia among all types of cultural identities either religious or ethnic were considered most important and were promoted by the state as reflected in the censuses of population. In addition, they have been interconnected.

The first general census of population of the Russian Empire was carried out in 1897. The census program was quite detailed. The cultural block of the program included questions about religion and native language, but did not contain a question about ethnic affiliation (Pervaia... 1905). Such choice of questions was no accident. The first census was preceded by serious preparatory work. In particular, Russian scholars involved in planning the census participated in the International Statistical Congresses. One of these congresses, which was held in St. Petersburg in 1872, debated the correlation between ethnic affiliation and native language. Ultimately, the census organizers preferred a question about native language; they based their decision on the rationale, typical for that time, that ethnic affiliation derives from a native language and religious affiliation. For example, Russian speaking people and the Christian Orthodox were assumed to be ethnic Russian.

As to a question about religious affiliation in the census, there were no debates at all about its inclusion into the census program. It was considered one of the most important factors of cultural identity. The 1897 census mate- 
rials contained 15 groups of religious affiliation denoting various denominations (Pervaia... 1905). The answer "non-believer" (or of something of similar sense) was not stipulated. All had to affiliate themselves with a particular denomination or confession. Hence, one can conclude that the census did not aim to fix the affiliation with a certain belief system, a person's world-view position (religious or secular), but did aim to fix religious affiliation as a factor of broader cultural identity, a person's belonging to a certain cultural and historic tradition based on religion. Russian legislation of that time also contributed to the comprehension of religion as first and foremost a collective cultural identity. The legislation ascribed everyone to certain faith by birth into a certain group that professed this faith. As with the 1897 census, the legislation of that time did not consider that a person would not belong to any faith (Bendin 2004: 119). The perception of religion as part of cultural tradition contributed to close intersections of religious and ethnic identities. Most of Russia's people were tightly connected with their "historic" faiths, which made those faiths a source of both religious and ethnic identities.

The next census took place in 1920 (Predvaritelnye... 1920-1921), already in the Soviet time, in fact just a few years after the establishment of a new regime. The timing indicates that the Soviet state placed great importance on the categorization of its population. Originally, the draft program of this census contained a question about religious affiliation, but on Lenin's personal request this question was excluded. His action is not surprising. The 1917 October Revolution proclaimed atheism to be the state ideology, religious beliefs were considered as vestiges, and religious identity officially lost its importance.

At the same time, ethnic identity became more meaningful. Its importance was promoted even by the reorganization of the administrative division of the state, which became connected with ethnicity. The Autonomous Republics and Autonomous Districts were named after the ethnic groups represented there, though these titular nationalities did not necessarily comprise the majority of the population of the corresponding body. Of course, the importance of ethnic identity was cemented by the census. All Soviet censuses contained questions about ethnic affiliation (based on selfidentification). All Soviet censuses also retained the question about native language.

The second Soviet population census was held in 1926. In comparison with all other Soviet censuses (both before and after), it fixed the most detailed ethnic categorization (Vsesouznaia... 1928). Interestingly, although it did not contain any question about religion, religious identification was indirectly involved. Among the instructions to census takers there was a list of five questions that were to be addressed to those who had difficulties answering the question about his or her ethnic affiliation. Out of these five questions, two were about religious affiliation: "In what faith were you 
born?" and "What is your faith now?" (Tishkov 2003: 194-195) It suggested that the census supervisors had no doubts about close connection of ethnic and religious identities.

The next census was conducted in 1937 (Vsesouznaia... 1991). It was the only Soviet census that asked about religion. There were two questions. First, a respondent should have answered if he / she was a believer. Then believers only were to indicate their religious affiliation. This question had a note: "Respondent's current personal religious convictions" (Cite from: Narodonaselenie 1994: 312). Both questions about religion were addressed only to persons 16 years of age and older. All this leads to a conclusion that the census composers tried hard to avoid the understanding of religious affiliation as belonging to historic tradition and cultural identity, which is closely connected with ethnic identity. Respondents were required to tell about their personal belief and their world-view rather than about their identification with a particular faith because of cultural and historic tradition. The goal of the inclusion of the question about religion into the census program was to demonstrate decline of religion - this "vestige" of previous times. To achieve this goal, religion and ethnicity had to be disconnected. It is evident that in 1937 many people were afraid to declare themselves believers. But still more than half of population called themselves believers, including 42.3 percent Orthodox (Vsesouznaia... 1991: 106-107). The interconnection between religion and ethnicity contributed to the maintenance of religiosity. The quite high level of religiosity shown by the census was one of the reasons why the 1937 census was declared defective and its results remained secret until the early 1990s.

A new census was held in 1939, but its results were published only in a very brief summary format. There were no questions anymore about religion in the 1939 census questionnaire.

In the post-war period, the USSR population censuses took place in 1959, 1970, 1979 and 1989 (TsSU... 1960; TsSU... 1971; Goskomstat... 1988; Goskomstat... 1989). As with other Soviet censuses, they contained questions about ethnic affiliation and native language. Starting in 1970 the forms also contained a question about speaking other languages. Hence, there were several questions connected to ethno-cultural identity. Yet there was no question about religion. At the same time, despite its atheist ideology, the Soviet society was not atheistic. People participated in some religious rituals and observed some religious holidays (or at least their elements). Yet, on a popular level, these manifestations of religiosity were more associated with ethnic culture. Even the state, being hostile to religious ideology and religious teaching, tolerated this kind of "ethnoreligiosity". For example, the Soviet stores sold so-called "Spring cake" - keks vesennii - before Easter.

The first post-Soviet census of population was held in 2002 (Vserossiiskaia... 2002). The new Russian government attached great importance to this census. It was expected to help constructing a new image of the state and its 
population (for example, elites of some ethnic groups who were fixed by the 1926 census and who later became assimilated into larger ethnic groups by later censuses now expected the census to recognize their ethnicity). There were many discussions about the categorization in the program of this census. The question about ethnic affiliation was kept in the post-Soviet censuses and the language block became even more detailed. Before the 2002 census, there were harsh debates about the inclusion or non-inclusion of the question about religious affiliation into the census program. On the one hand, these debates reflected the increased role of religion. On the other hand, there was an attempt to cater to the perception that there should be a separation of church and state, meaning that the state should avoid any religious matters on the official level. These debates resulted in the omission of any question regarding a religion affiliation into the 2002 census.

The question about religion did not appear in the program of the 2010 census either (Vserossiiskaia... 2010), and it is not planned for the 2020 census. This means that a religious affiliation is not included into the officially recognized major categorization of population. At the same time, religion is heavily present in the public space with church and state closely cooperating in some spheres. All this reinforces the cultural component of religion and strengthens the interconnection and interpenetration of religious and ethnic identities. As before, religion and ethnicity are closely connected in Russia. But unlike the 19th century when religious identity was basic while ethnic identity was derivative (from religion and native language), nowadays ethnic identity is basic while religious identity often derives from it. When surveys ask, "What is your religion?" the response frequently is, "I am Russian, hence I am Orthodox." A historic faith is deeply incorporated into ethnic culture, traditions, and common memory. This makes it important even for nonbelievers. That is why the affiliations like "I am a nonbeliever of Orthodox heritage" (Ia neveruiushchii iz pravoslavnykh) would also be present in surveys.

Finally, what type of religiosity does this link between religion and ethnicity produce?

The interconnections of religion and ethnicity influenced the relatively low numbers of those who call themselves non-believers in a society where atheism had been the official policy for over seventy years. Due to the ethnization of religion, atheism in the USSR was superficial. Soviet society was very secular, but not atheistic. Since religion was engrained into ethnic culture, people wanted to have their children baptized, to have religious rituals performed for their deceased relatives, to have special cakes (kulich; "spring cakes" according to the stores' labels) and colored eggs on the Easter table and so on. The connection between religion and ethnicity did not allow the Soviet state to remove all sorts of religious practice and rituals from the life of Soviet citizens, because religious rituals were considered as part of ethnic 
cultural traditions. Yet, the strong connection between religion and ethnicity resulted in the formation of so-called folk Orthodoxy (or popular Orthodoxy) characterized by a lack of religious rigor, neglect of dogmatic teachings, incorporation of the elements of pre-Christian belief systems, particular adoration of most favorite, beloved saints viewed as protectors of certain spheres of life and activities, and reinterpretation and ethnization of religious holidays. This folk Orthodoxy, deeply intertwined with ethnic traditions, helped to preserve the Orthodox faith during the atheistic Soviet period and eased the subsequent return of the official church into the public realm and the life of population. However, this popular type of religiosity, connected with ethnicity, also has contributed to the growing gap between official Orthodoxy and folk Orthodoxy, and the gap between those who believe and practice religion and those who associate themselves and observe certain (or chosen) ethnicized religious rituals.

Folk Orthodoxy can serve as a resource for the Church. At the same time, however, the elements of folk Orthodoxy tend toward superstition. In such cases, venerators of holy objects and sites seek a practical payoff, and, as a result, their religiosity is very different from the practice of religion in the correspondence with the Church canons (Burgess 2017: 212). These "faithful" immerse themselves into the ice-hole on the Epiphany to wash off jinxes and renovate the body. They also observe the food restrictions during Lent as a helpful diet. The re-imagination of religious attributes and symbols and their incorporation into the scope of cultural tradition secularized some of them (not without the help of the Soviet state). Thus, a Christmas tree was converted into a New Year tree in Russia, and, for this reason, it lost any connection to Christianity, becoming a New Year attribute in the homes of Christians, Muslims, Jews, believers and non-believers alike.

The close connection between religious and ethnic identities explains the inconsistent and even irrational behavior of some non-believers when they are drawn into some sort of religious performance: they observe religious holidays, sometimes attend church services and participate in some religious rituals. Doing all these things they view them as a part of cultural and ethnic tradition - a cultural norm of their ethnic group.

It has been typical for many Russian citizens to approach religion primarily not as a theistic world-view but rather as part of cultural tradition. Yet, this cultural component of religion potentially opens doors to practical religiosity. Surveys confirm that during three post-Soviet decades the numbers of believers have increased (although not drastically).

There is another consequence of the interconnection of religion and ethnicity and cultural understanding of religion. Religion is viewed as a force of cultural tradition. In its turn, it justifies the state involvement in framing religious ideology and leads to the connection of religious identity not only with ethnic but also with national (civic) identity. Since 1993, the Russian Ortho- 
dox Church has been holding the World Russian People's Councils (Vsemirny Russki Narodny Sobor) with social issues on their agenda, which also reflects the connection of religious identity with ethnic and civic identities and the recognition of these ties by the church. The ideas of the "Russian world" and "particular Russian civilization" also reflect the meaningfulness for the Church of the links between religiousity and ethnic / national identity. Here one sees the tendency of homogeneity of the Orthodox Church, the Orthodox nation and the Russian culture, a genre that is being called "ethnotheology" as suggested by Aristotle Papanikolau (Papanikolau 2012: 44). The 18th World Russian People's Council (2014) showed an example of such ethnotheology when it adopted the "Declaration of Russian Identity" and formulated the concept of Russianness, connected to the Christian Orthodox faith (Deklaratsia... 2014). The Declaration says that "the Orthodox faith has played a key role in the forming of Russian identity. On the other hand, the events of the 20th century demonstrated that a significant number of Russians became non-believers, but they did not lose their national selfconsciousness. And still, the claim that every Russian should accept Orthodox Christianity as the basis of his or her national culture is justified and fair. Denying this fact or even searching for another basis of national culture would testify to the weakening of Russian identity to the extent of its complete loss" (Deklaratsia... 2014).

Summing up, the place of religious identity in the hierarchy of cultural identities in Russia has changed over time. But in all times, it has been closely connected with ethnicity. The categorization in the censuses of population contributed to interconnection of religious and ethnic identities, regardless of which of them was promoted by the state at a given period. This close connection in its turn has determined the type and specifics of religiosity in Russia today.

\section{References}

Bendin A.Yu. Veroterpimost' i Problemy Natsional'noy Politiki Rossiiskoy Imperii (vtoraya polovina XIX - nachalo XX veka) [Religious tolerance and issues of the Russian Empire's nationalities policies (second half of the 19th - beginning of the 20th centuries)], Tserkovno-istoricheskiy vestnik, 2004, no. 11, pp. 113-137.

Burgess, John. Holy Rus'. The Rebirth of Orthodoxy in the New Russia. New Haven: Yale University Press, 2017.

Deklaratsia Russkoi Identichnosti [Declaration of Russian identity]. 2014. Available at: http://www.vrns.ru/news/3398 (Accessed 25 August 2019)

Goskomstat SSSR. Naselenie SSSR. Statisticheskii Sbornik [USSR State Committee on Statistics. USSR Population. Statistical almanac]. Moscow: Goskomstat SSSR, 1988.

Goskomstat SSSR. Itogi Vsesouznoy Perepisi Naselenia $1989 \mathrm{~g}$. [USSR State Committee on Statistics. The results of the 1989 all-union census of population]. Moscow: Goskomstat SSSR, 1989.

Kertzer David I., Arel Dominique. Census, Identity Formation, and the Struggle for Political Power. In: Census and Identity. The Politics of Race, Ethnicity, and Language in National 
Censuses. Ed. by Kertzer David I., Arel Dominique. Cambridge: Cambridge University Press, 2002, pp. 1-42.

Narodonaselenie. Entsiklopedicheskii Slovar' [Population. Encyclopedic dictionary]. Moscow: Bolshaia Rossiiskaia entsiklopedia, 1994.

Papanikolaou, Aristotle. The Mystical as Political. Democracy and Non-Radical Orthodoxy. Notre Dame (Indiana): University of Notre Dame Press, 2012.

Pervaia Vseobshchaia Perepis' Naselenia Rossiiskoi Imperii 1897 g. Kratkie Obshchie Svedenia po Imperii. Raspredelenie Naselenia po Glavneishim Sosloviam, Veroispovedaniam, Rodnomu Yazyku i Nekotorym Zaniatiam \{1897 first general census of population of the Russian Empire. Concise general data for the Empire. Distribution of population on basic classes, faiths, native language and certain occupations]. St. Petersburg: Izdatelstvo Tsentralnogo Statisticheskogo Komiteta Ministerstva Vnutrennikh Del, 1905.

Predvaritelnye Itogy Perepisi Naselenia 28 Avgusta 1920 g. Tom 1. Vyp 1-5 [Preliminary results of the census of population of 28 August 1920. Volume 1. Iss. 1-5]. Moscow: Trudy Tsentralnogo Statisticheskogo Upravlenia, 1920-1921.

Principles and Recommendations for Population and Housing Censuses. Revision 1. United Nations. New York, 1988. Para 1.1.

Prodromou Elizabeth H. Orthodox Christianity and Pluralism. Moving beyond Ambivalence? In: The Orthodox Churches in a Pluralistic World. An Ecumenical Conversation. Geneva, Brookline (Massachusetts), 2004, pp. 22-46.

Tishkov V.A. Rekviem po Etnosu. Issledovaniya po Sotsial'no-kul'turnoy Antropologii [A Requiem for ethnos. Research on social and cultural anthropology]. Moscow: Nauka, 2003.

TsSU SSSR. Itogi Vsesouznoi Perepisi Naselenia 1959 Goda [USSR Central Statistical Bureau. The results of the 1959 all-union census of population]. Moscow: TsSU SSSR, 1960.

TsSU SSSR. Itogi Vsesouznoi Perepisi Naselenia 1970 Goda [USSR Central Statistical Bureau. The results of the 1970 all-union census of population]. Moscow: TsSU SSSR, 1971.

Vserossiiskaia Perepis' Naselenia 2002 g. Tom 4. Natsionalnyi sostav i Vladenie Iazykami, Grazhdanstvo. Itogi Vserossiiskoi Perepisi Naselenia 2002 goda. Ofitsialnoe Izdanie [2002 All-Russian census of population. Volume 4. National composition and language proficiency, citizenship. The results of the 2002 all-Russian census of population. Official edition]. Moscow: Federalnaia Sluzhba Gosudarstvennoi Statistiki. Statistika Rossii, 2004.

Vserossiiskaia Perepis' Naselenia 2010 [2010 All-Russian census of population]. Available at: https://www.gks.ru/free_doc/new_site/perepis2010/croc/perepis_itogi1612.html (Accessed 25 August 2019)

Vsesouznaia Perepis' naselenia 17 Dekabria 1926 g. Kratkie Svodki. Vypusk 4. Narodnost i Rodnoi Iazyk Naselenia SSSR [All-union census of population of December 17, 1926. Concise reports. Issue 4. Nationality and native language of the USSR Population]. Moscow: Izdanie TsSU SSSR, 1928.

Vsesouznaia Perepis' Naselenia 1937 g. Kratkie Itogi [1937 All-union census of population. Concise Results]. Moscow: Nauka, 1991.

Zaluzhnyi A.G., a.o. Mnogonatsionalnaya Rossia. Dialog Religiy i Kultur. Rol' Religioznykh Ob'edineniy v Mirotvorcheskoi Deyatel'nosti, Ukreplenii Mezhreligioznogo Soglasiya i Druzhby Narodov [Multinational Russia. Dialogue of religions and cultures. Role of religious associations in peacekeeping, strengthening of interreligious accord and friendship among peoples]. Moscow: Gotika, 2002. 